on flying up, with a few swift and deft movements of the bill, exposed the eggs and made a rapid meal of them.

Sealing sloops make the journey each summer from northern Norway to Spitsbergen to gather eggs and down of the eider duck. The down is used for quilts, and the eggs are sold in the northern towns and villages of Norway, where the domestic hen (perhaps because of the difficulty of feeding it through the long Arctic winter) is rarely seen.

The eider duck is an assiduous diver, and most of its food is taken from the floor of the ocean. It is particularly fond of mussels, and the fishermen of the north-east coast have tamed eider ducks in a remarkable manner by feeding them on the mussel bait that is wasted when a sudden change of weather with rough seas, occurring after the mussels have been shelled, prevents the lines being baited with them. The eider duck feeds also upon limpets, periwinkles and razor-shells, and has been known to swallow razor-shells up to ten inches long. Small crabs, sea-urchins and star-fish are also eaten. Eider ducks are expert divers, but they do not like a rough sea, and are not happy in turbulent breaking waves where scoter and scaup are often seen swimming and diving. Eiders, both ducks and drakes, often land on some low skerry on a falling tide, and stand contentedly, dozing or preening their feathers, but the eider duck very rarely ventures above high tide-mark except during the nesting season.

I do not remember having seen an eider drake at any distance from the tide except on one occasion. This was early on a May morning, in the Isle of Skye. I was motoring along the main road between Portree and Kyleakin, and where the road skirts Loch Ainort and winds along the hill-face at a height of perhaps one hundred feet above the sea, I saw on the road what at a distance I thought was a seagull. But as I approached I saw that this was no gull, but an eider drake, and as the car neared him he flew out over the heather-covered hillside and then out over the sea. He may have been accompanying his duck in a search for a suitable nesting place, but if the duck was in the neighbourhood she did not appear, nor did she fly away with the drake.

The eider lays four to six large unspotted eggs of a greenish colour, and when she is suddenly disturbed from them she fouls her nest as she flies off, presumably to render the eggs less attractive for an animal which might otherwise make a meal off them. The ducklings take to the sea on the day they are hatched, and are able to swim and dive actively. They are excellent divers even from their earliest youth, and are able to survive and even to enjoy breaking waves, diving through them and keeping pace with the mother without diffculty. But a prolonged period of rough and cold weather soon after they are hatched is fatal to the weaker members of the broods, and a mother eider duck may often be seen with only a single duckling following her. The young ducklings have many enemies, and perhaps the most ferocious is the greater black-backed gull, which pounces down upon an unattended duckling and swallows it whole.

\title{
Obituary
}

\section{Prof. Christian Hülsen}

$\mathrm{W}$ $\mathrm{E}$ regret to record the death of Prof. Christian Hülsen, the archæologist, which took place at Florence on January 19 at the age of seventy-six years.

Christian Hülsen was born at Charlottenburg and was educated at the University of Berlin, where he came under the influence of Theodor Mommsen, the Roman historian. From 1882 until 1885 he studied in Italy as a travelling scholar of the Archæologieal Institute. He returned to Berlin as a schoolmaster, but in 1887 he became a secretary of the German Archæological Institute in Rome, where he remained until his retirement in 1909 . He then took up his residence in Florence and devoted the remainder of his life to writing and research.

Hülsen's main life-work as an archæologist lay in the two departments of epigraphy and topography. As an authority on the Rome of the classical, medieval and Renaissance periods he was without a rival, with the exception of the late Prof. Lanciani. His book on the Forum and its excavation by the Com. Boni achieved a wide popularity, while for more serious students his account of the excavations on that site and on the Palatine, published in 1928, is a standard of reference. Of an even more authoritative character is his "Formæ Urbis Romæ antiquæ", which is especially of value to the student for its plans of the ancient city, and its index and bibliography of the monuments. In the study of medieval and Renaissance Rome, his outstanding contributions were the publication of the Barberini codex of Giuliano de Sangallo and of the Berlin drawings of Marten van Heemskerch, the latter in collaboration with Hermann Egger. His "The Churches of Rome in the Middle Ages" is a mine of valuable detailed information.

In epigraphy Hülsen's immense fund of knowledge of Roman topography served him well in compiling the inscriptions of the city of Rome for the "Corpus Inscriptionum Latinarum". In addition to his other work which appeared in book-form, he was the author of a large number of contributions to archæological periodical publications in both Italian and German. 
Hülsen was an honorary D.Litt. of the University of Oxford and of Columbia University, New York, where he had delivered a course of lectures. In 1917 he was appointed honorary professor in the University of Heidelberg, and shortly before his death he was informed of his election to be one of the nine honorary members of the Pontifical Academy of Arts and Archæology, Rome.

\section{Mr. JoHn Fraser}

John Fraser was born on Jamuary 31, 1854, at Newdeen, Fraserburgh, Aberdeenshire, and died in Charing Cross Hospital on January 24, 1935, from pneumonia following injuries received in a road accident.

Mr. Fraser was well known both as a horticulturist of high repute and as a critical student of the British flora. In horticulture he received training at the old ('hiswick gardens of the Royal Horticultural Society and at Kew. In May 1885 he commenced work in the Jodrell Laboratory, Kew, for Sir John Lubbock, afterwards Lord Avebury, and the connexion thus established lasted for many years. Fraser was responsible for much of the detailed work underlying Lord Avebury's classical researches on seedlings, pollen, buds, stipules and other botanical subjects. $\mathrm{He}$ also edited or contributed to many well-known horticultural publications.

As a field collector and observer and a herbarium investigator, Fraser was held in high esteem by a wide circle of botanical friends. In his later years he specialised on the taxonomically difficult genera
Mentha and Salix, and his published accounts of these genera give evidence of a elear logical mind and considerable ability in concise description. His fine herbarium collections of about nine thousand sheets, together with his manuscript notebooks, have been presented, at his written desire, to the Royal Botanic Gardens, Kew, by members of his family. There are many valuable Scottish gatherings among his specimens, and the flora of Surrey is particularly well represented. His collection of seedlings of British plants, numbering several hundred sheets, must be unique, and will be of great value in future investigations of life-histories.

Fraser was elected a fellow of the Linnean Society in 1889 , and the Council of the Royal Horticultural Society conferred on him the Victoria Medal of Horticulture in 1922 and the Veitch Memorial Medal in 1929.

W. B. TurRILL.

$W_{\mathbf{E}}$ regret to announce the following deaths :

Mr. Eric H. S. Bruce, editor of the Aeronautical Journal in 1899-1908, well known for his work in aviation, especially on balloons, kites and airships, on February 28, aged eighty years.

Prof. William Duane, professor of biophysics in Harvard University since 1917 , an authority on radioactivity and $\mathrm{X}$-rays and their application to the treatment of disease, aged sixty-three years.

Mr. W. J. A. Grant, a member of several Aretic expeditions, after whom Cape Grant in Alexandra Land was named, on March 10, aged eighty-three years.

\section{News and Views}

\section{A British Magnetic Survey Vessel}

THE explanatory statement by the First Lord of the Admiralty, which was presented with the Navy Estimates for 1935 to the House of Commons on March 6, contained the interesting information that it has been decided to construct a magnetic survey vessel. A first instalment of $£ 10,023$ towards the construction of this vessel has been included in this year's estimates. The unfortunate destruction by explosion and fire of the Carnegie on November 29, 1929, while in harbour at Apia, Western Samoa, brought the valuable work which had been carried on by this ressel to a sudden conclusion. Constructed for, and maintained by, the Carnegie Institution of Washington, she had in six cruises between 1909 and 1921 traversed 252,702 nautical miles in 3,267 days actually at sea. Of the seventh cruise of 110,000 nautical miles, nearly one half had been completed upon the arrival of the Carnegie at Apia; this cruise was planned particularly with the view of determining magnetic secular variation.

THE magnetic charts published by the British and other Governments for use at sea have been based in recent years to an increasingly large extent upon the data provided by the Carnegie. There are some serious gaps in the present data, which would have been filled if the Carnegie had completed her last cruise. Due partly to these gaps and to a recent rapid change in the secular variation in the Indian Ocean, the extrapolated values of the magnetic elements in the southern Indian Ocean are now unreliable, and the possibility of serious errors in this and other areas in future charts has given rise to some concern. The Carnegie Institution, having definitely decided not to replace the Carnegie, and in view of the special interest of Great Britain, as the principal maritime nation, in the accuracy of the magnetic charts, the British Government has assumed the responsibility. A non-magnetic ship is to be constructed, primarily for the purpose of determining magnetic data at sea. Details of the design have not yet been decided upon, though it is probable that the new vessel will be larger than the Carnegie.

\section{Refugee Scholars}

A PAMPHLET entitled "A Crisis in the University World" issued last week by the High Commissioner for Refugees from Germany (obtainable free of charge from the General Secretary, Academic Assistance Council, Rooms of the Royal Society, Burlington House, W.1) gives an account of the assistance to displaced German scholars and men of science during the past two years. Approximately 650 of the 